\title{
Gender Equality Rights Discourse in Indonesia: Muhammadiyah Reading Models
}

\author{
Agus Miswanto ${ }^{1 *}$ \\ ${ }^{1}$ Department of Islamic Economics Law, Universitas Muhammadiyah Magelang, Magelang, Indonesia \\ *Corresponding author. Email: agus_miswanto@ummgl.ac.id
}

\begin{abstract}
Renewal in the Muslim world, still leaves problems in gender relations. Not a few, some reforms have actually reduced the role of women only in the domestic sphere. This research looks at the model of reading gender discourse in Muhammadiyah, which is known as a reformed organization in Indonesia. This study uses discourse analysis to reconstruct the gender discourse in Muhammadiyah, which is developed in varied forms of decisions, policies and ijtihad method. From this study it was found that Muhammadiyah was very appreciative of gender equality rights. Muhammadiyah has a progressive-critical reading on gender relation such as: 1) emphasizing al-ijtihad as a way to parse the problem, not leaving the problem to the results of past al-ijtihad of classical Muslim scholars; 2) not accepting the dalil da'eef (weak proposition) to be practiced, which in general is considered to be very misogynous; 3 ) not stop at the textual domain, but the interconnection between text and context.
\end{abstract}

Keywords: gender, women rights, Muhammadiyah

\section{INTRODUCTION}

Gender inequality is still a major debate among intellectuals. Many experts argue that gender injustice is caused by the patriarchy domination over women in various forms and levels[1]. Likewise in Islam, the struggle for gender discourse still leaves much debate which has not yet been resolved. In various academic forums, organizations, and even religious fatwas, gender issues become a hot topic of discussion. Within the Muhammadiyah organization, gender discourse is also often a debatable topic, but the debate does not reduce the gait of women in the public sphere, but precisely and increasingly it supports and strengthens the role and involvement of women in social and political life in the modern world. In 2015, the Muhammadiyah Tarjih Council conducted a Working Group Discussion that raised the theme specifically for women in the Muhammadiyah's view, which presented experts and stakeholders within Muhammadiyah [2][3].

In various studies, in the Islamic world, Muslim women still have not enjoyed their full rights. Moghissi [4], Kostenko [5] and Glass [6] confirm in their research, that most Muslim women actually get strict restrictions and enjoy less freedom, as happened in Saudi, Afghanistan, Sudan, Iran and some North African countries like Algeria. According to Moghisi [4] and Kostenko [7], that Muslim women are increasingly restricted to taking part in the public sphere, are due to the strengthening of fundamentalism in these countries. Likewise, a study conducted by Klingorová and Havlíček [8] showed that Muslim women experienced more gender injustice in the Muslim world. While Gouda and Potrafke's study shows that women experience discrimination in Muslim-majority countries, both said the following:

"Discrimination has been documented against women in Muslim-majority countries. Constitutions differ among Muslim-majority countries. By using women's rights indicators and exploiting cross-country variations, we find that discrimination against women is more pronounced in countries where Islam is the source of legislation"[9].

In Indonesia, gender discourse in many Islamic organizations also struggles to attract the role of women into the domestic sphere, and reduce public life, this can be seen in salafi movement. In his study, Kusmana [10] showed that Salafi are an anti-democratic group that imposes very strict restrictions on women. According to Iffah Muzammil [11], this is because Salafi tend to literal-textual understanding, fixated on strict texts, and tend to al-takfiri paradigm ideology, which is to easily disbelieve and excludes others who are not in line with their beliefs. Likewise, in the Tarbiyah movement in Indonesia, as shown by Ai Fatimah Nur Fuad's research [12], that life relations between men and women are increasingly subjected to a tight segregation. Likewise, the lives of women in traditional Islamic organizations are still struggling with past thoughts, most of which are not appreciative of the role of women in the public sphere.

Compared to other Muslim women, Muhammadiyah women are more fortunate in terms of equality. This, according to M. Amin Abdullah [13], is due to the fact that in Muhammadiyah there are strong practices regarding equality in relations between men and women, for example in the context of strengthening women's leadership in the Muhammadiyah environment. Syamsiatun's research [14] shows that the gender movement in Muhammadiyah is not only oriented towards practical interests but also strategic interests, namely strengthening the position of women in public leadership. In other words, Muhammadiyah women enjoy more freedom compared to women in other Islamic organizations. The breadth of the role of Muhammadiyah women is shown in their involvement in social-political life. 
In social life, Muhammadiyah women are active in many Muhammadiyah business charities which are quite widespread, and they are one of the key factors in the success of these charitable ventures. And not a few, among them became successful leaders in moving and organizing the Muhammadiyah social charities. Therefore, the question in this study is how the reading model of Muhammadiyah in the texts related to gender roles for advocating and mainstreaming women as public leaders is?

\section{METHOD}

This research is a descriptive-analysis-qualitative study. This research tries to describe the gender discourse in Muhammadiyah by using qualitative content analysis. The gender discourse in this research is related to women's public leadership and women's active role in other areas of public life. The both issues are often raised in the arena of gender discourse about women in both national and international contexts. By using the theory of discourse analysis, this research tries to reveal Muhammadiyah's ideological decisions about women. The main object of this research is the book of Adabul Mar'ah Fil Islam and the Book of Himpunan Putusan Tarjih Muhammadiyah (the Muhammadiyah Tarjih Verdict Collection), which contains the religious guidelines of Muhammadiyah group members in daily life. The both books serve as a basic guideline for Muhammadiyah people through the decision of the Tarjih Council, an institution that has special and official authority in providing religious decisions [15].

The Book of Adabul Mar'ah Fil Islam contains specifically about the guidelines, ethics, and social relations of Muhammadiyah women. This book was compiled through a very long process to become an official guide in Muhammadiyah, which is about 10 years between 19721982. This book contains nine chapters of discussion, namely women and relationships, dressed according to Islamic guidance, parades and demonstrations, women and arts, women and science, women and Jihad, women in political Islam, and finally women to be judges. This research is only limited to the chapter on the parade procession and demonstration, the chapter of Muslim women in politics, and the chapter may women be judges. And the second book that is the object of research is the Muhammadiyah Tarjih Verdict Collection (HPT). This book contains general guidelines on matters of aqeedah (belief), worship, worldly al-muamalah and morals. Relates to study of HPT book, it only focuses on issues concerning the parade procession and demonstrations.

In addition to the two books above, this research also tries to look at official documents about Muhammadiyah's ideology that are relevant to help understanding and analysis of the two books, such as the Matan Keyakinan (platform of ideological beliefs in Muhammdiyah) and other decisions.

\section{RESULTS AND DISCUSSION}

\subsection{Muhammadiyah Modernism Paradigm}

Muhammadiyah is known as the modern Islamic movement in Indonesia which was founded by KH Ahmad Dahlan in 1912, in Yogyakarta [16][17][18]. Commonly, the main character of Islamic modernism movement is returning to the spirit of the Qur'an and Sunnah, and not trapped in the cult of past thoughts (taqdis al-afkar al-qadimah). Avoiding the cult of thoughts of the past, it requires Muhammadiyah to make continuous al-ijtihad efforts, so that the wheel of thought does not freeze and stop. Fauji Koda[19] states, that the al-ijtihad paradigm of Muhammadiyah is a dialectical process between text and context. In the Muhammadiyah view, ijtihad is a historical necessity by understanding and placing the text in its context. Therefore, within the Muhammadiyah, the results of al-ijtihad of past scholars (ulama) are placed in their own past historical time, and there is no obligation for today generation to follow the thoughts (ijtihad) of past scholars. According to Muhammadiyah, issues of the present era belong to the responsibility of today generation, who must answer and solve it with their capabilities in doing al-ijtihad.

The spirit of modernism is a feature of Muhammadiyah movement, where welcome the progressive path for the future. Muhammadiyah abandons past unimportant thoughts (al-furu'iyyah) that use up energy in critique of discourse, which other Islamic groups (organizations) are trapped in and very difficult to get way out. In Muhammadiyah perspective, past thoughts are not something sacred and not taken for granted, but of those that are very problematic and irrational are abandoned; then looking forward to welcome the progress of civilization with a new perspective and optimism. Muhammadiyah welcomes a spirit of progressive and responsive Qur'anic values, and leaves the debates about old thoughts that are obsolete to be carried forward. Burhani's research [17] shows that, KH A. Dahlan, as the founder of Muhammadiyah, tried to interpret and understand the Koran in accordance with the modern context. He took the meaning of religious doctrine to be actualized for social reform. Therefore, Dahlan is well known as a very tolerant, open and pluralist figure.

The spirit of modernism in gender, Muhammadiyah does not rely on the understanding of classical scholars who tend to be gender biased. In the discourse of gender sensitivity and relations, Muhammadiyah continues to engage in alijtihad and build its own rules which form the foundation of the life of a modern Muslim family. Muhammadiyah developed its own gender teaching guidelines for its members, namely the book of adab al-mar'ah fil-Islam which was published in 1982 [20]. In Muhammadiyah the culture of adhering to the propositions of the Koran and Sunnah was developed as a reference, not holding to the opinion of a mujtahid in the past, by using the classical Islamic book without criticism. Therefore, in the Muhammadiyah schools or boarding schools there is no reference such as Uqudul Lijain [21] to be instructed, which is known as a book-based biased gender teaching which has always been a standard guideline for teaching gender in 
various pesantren in Indonesia. Ahmad Khozin's research on the Uqudul Lijain found many hadiths in the book were invalid, or da'eef [22]. Thus, the teachings of these traditions cannot be practiced (ghairu makmul). Besides that, even though there are valid traditions, narrative reading must be read holistically with the linkages of events and historical circumstances of the past.

The debate over gender discourse in Muhammadiyah actually rests on the progress and enlightenment of women. Therefore, gender discourse in Muhammadiyah relies more on the value of women's freedom and glorification, as well as the spirit of participation in public life.

\subsection{Dynamics and Static Framework}

The progressive method of Muhammadiyah in the reading of the Shari'a lies in the formation of the Shari'a which is broadly differentiated in two frameworks, namely altsawabit (static) and al-mutaghayyirat (dynamic), which in Anwar's term, are called as purification and dynamization [23]. This can be seen in the Muhammadiyah doctrines platform, which is known as Matan Keyakinan. In this Matan Keyakinan, it is stated that Islamic law is divided into four areas, namely aqeedah, worship, muamalah, and morals [16]. This trial has methodological implications related to the reading of progressive gender discourse in Muhammadiyah. The aspects of aqeedah and worship are dimensions of al-tsawabit (static) which do not accept changes that are kept in its purity. So that Muhammadiyah is known to be very puritanical in aspects of aqeedah and worship. On the other hand, the aspects of al-mumalah and morals are al-mutaghayyirat (dynamic) aspects, which practically can changes along with the development of the situation and time. Therefore, in aspects of al-muamalah and morals, Muhammadiyah is known to be very progressive, which is always dynamic in responding to every problem that develops in relation to universal humanity (rahmatan lil 'alamin).

Sometimes in practice, ideological battle situation between puritanism and progressive group in Muhammadiyah is feared by a few intellectuals. Suaidi Asyari [24] for example, perceived that it would drag Muhammadiyah into Islamism. In opposite, Burhani's research [23], shows that although the wings of puritanism and progressiveness in Muhammadiyah drag each other in the opposite direction, but Muhammadiyah is not trapped on one of these wings but instead places itself on the moderate line. The ability of Muhammadiyah to position itself in the moderate religious line, because Muhammadiyah according to Burhani [23] and Aminullah Elhady [25], is more concerned with social empowerment than the theological discourse that runs, while Masdar Hilmy [26] looks at theological views that are non-violent, respect for human rights, and accept the idea of the Pancasila as a state ideology of Indonesia.

In Muhammadiyah, gender discourse is included into the category of muamalah (worldly Islamic law), an aspect of al-mutaghayyirat (dynamization), which is developed to answer and respond to the needs of modern women, which do not abandon the spirit and core values of Islamic teachings. Therefore, shifting paradigms related to gender issues is actually not troubling within the Muhammadiyah environment, because it is growing in the corridor of discourse in the aspect of fiqh al-muamalah. Even M. Amin Abdullah, well-known as a Muhammadiyah prolific thinker, proposed a paradigm shift in the proposition of Fiqh in the classical-scholastic era that was more ad hoc, partial, particular into the paradigm of the Usul al-fiqh of modern era and even advanced modern era, which was more friendly to universal humanitarian problems. There for, he perceives that it is very important to break out of the old Usul al-fiqh in understanding tradition [13][24].

Furthermore, according to M. Amin Abdullah, that classical Islamic scholarship is more concerned with the biological aspects (nature) of the human body. All stereotypical reading of women begins from the standpoint of nature (natural) or biology. It's really different between male and female bodies when viewed from a biological perspective. The chapters in al-fiqh always focus on discussing menstruation, women's voices, giving birth, breastfeeding, genitalia, al-hijab, al-muhrim and so on. A life task that cannot be exchanged between men and women, between men and women. While the concept of Gender (some contemporary Arabic writers refer to it as Fiqh al-Nisa' alMu'asir, ie Contemporary Women's Jurisprudence) is a way of reading and analyzing advanced modern and modern scholarship that is more observing social roles (leadership, economic, social, political, culture) which can be played by women in private and public spaces. Actual roles can be exchanged between men and women, between men and women [13][24].

Amin Abdullah's perspective above turns out to have been practically carried out by Muhammadiyah in responding to contemporary women's problems. This can be seen from various interpretations and also Muhammadiyah's decisions regarding gender relations. Methodological implications can be seen from various aspects of Muhammadiyah's interpretation in answering contemporary problems of women. In the context of women's leadership for example, according to Tafsir [3] that women in the Muhammadiyah perspective have the same abilities and rights as men. As revealed in the Adabul Mar'ah Fil Islam, as follows:

"How does a woman become a judge, school director, company director, sub-district head, village chief, minister, mayor, etc.? Religion does not give a reason for those who reject or obstruct" [20].

The explanation above shows that women in Muhammadiyah's perspective are positioned to have equal abilities with men, including in the context of public leadership. This is also supported by the latest decision of Muhammadiyah[15], which states that men and women alike as the caliph of Allah on earth. This shows that men and women do not have different functions in public life. And when confronted with the hadith of the Prophet SAW which explains that "a people will not succeed when lifting women as their leaders", the Muhammadiyah Tarjih Council explained that the hadith must be placed in the context of historical past.

"Based on the historical process of human life hundreds of years ago, we can understand the jumhur al-ulama's expression based on the interpretation which explains that women absolutely must not hold positions / positions of leadership, in the midst of social life". 
"Even though we should interpret the hadith as a temporary expression that is associated with certain images at certain times and certain forms that have been experienced by humankind in the distant past. A situation that is difficult to find in the present. Thus in this day and age it seems no longer questionable: Can women be judges?" [20].

In al-turast (legacy of thought) of Islam, the term leadership is expressed in various terms, including Khilafah, Imamat, walayat, Imarah, Riyasah, and ra'iyyah [25][26]. According to Muzzakir [27], that the leadership of women (imamat almar'ah) also became part of the issues discussed by the scholars in the al-turast since the classical period. In short it can be said here that the general tendency prevailing among the ulama is to reject women's leadership. Ibn Hajar alAsqalani [28], for example, reported the following: "using argument with the hadith Abi Bakrah people who view should not assign women to as a judge and this is the opinion of the majority of scholars ". Ibn Hazm al-Dhahiri [29] even claimed that women should not become leaders is an agreement of the scholars. In his book Maratibul Ijma' he wrote: "from the whole Muslim group no one allows women's leadership".

Muhammadiyah through the Tarjih Council took a different way of thinking from the perspective of the Muslim scholars above. In the Adabul Mar'ah Fil Islam, it is stated that "there is no reason in religion to refuse women to become judges, school directors, company directors, sub-district heads, village heads, ministers, mayors and so on". In the discourse of Women in al-fiqh, the statement was reiterated again that for a position as president, women could occupy it [20]. In the 1997 Tarjih Fatwa also contained a statement, "The Muhammadiyah Council of Tarjih did not see any propositions which are texts for the prohibition of women becoming leaders". From the above quotations it can be concluded that the Muhammadiyah's view of women's leadership, both at the lower level (district), the community, to the public domain as president, which in classical fiqh is called the al-imamat al-uzma (the greatest leadership), is a supportive and appreciative view [27].

\subsection{Religious Text Criticism}

In accepting the proposition, Muhammadiyah was critical and conducted an in-depth study. Based on the naqd alriwayat (historical criticism) or al-dalalat (legal appointment), the texts of al-dalil are divided into aldhaniyyat (uncertainty) and al-qathiyyat (certainty). The proofs of al-qathiyyat are certainly accepted without exception, while the propositions that are al-dhaniyat must be studied in more depth, then finally it is obtained a sahih and hasan qualification proposition. Thus Muhammadiyah does not accept the traditions of Da'eef (weak) unless there are many mutually reinforcing paths so that they can occupy positions of hasan lighairih [30]. As an example of the procession, marches and demonstrations, through the Tarjih Council, Muhammadiyah gave the following fatwa:

"When the procession, march, demonstration and others are for the sake of religion or for the benefit of not violating the provisions as mentioned above, there is no obstacle" [31]. The above statement was issued, after the Tarjih Council had conducted research and made a comparison of the various propositions that were circulating, as well as conducted an examination of its existing arguments. And after testing the history (criticism) of the al-sanad (transmission chain) of the Prophet's traditions narrated through Ibn Umar by al-Thabrani, which states that women are prohibited from leaving the house except under forced conditions, it turns out to have a weak quality (dha'if), cannot be used as al-hujjah (argument) [20][22]. And ironically, these traditions are widely circulated and are often used as an argument against restrictions on women's freedom. To counter the arguments, besides making criticisms of the arguments, Muhammadiyah is looking for other arguments that have strong arguments. In other words, the reading of the Muhammadiyah upon text does not stop at a single text, but Muhammadiyah tries to make comparisons, integration and interconnection with other texts, so that an appropriate legal conclusion is found. In comparing arguments, Muhammadiyah proposed two propositions from the hadith as follows:

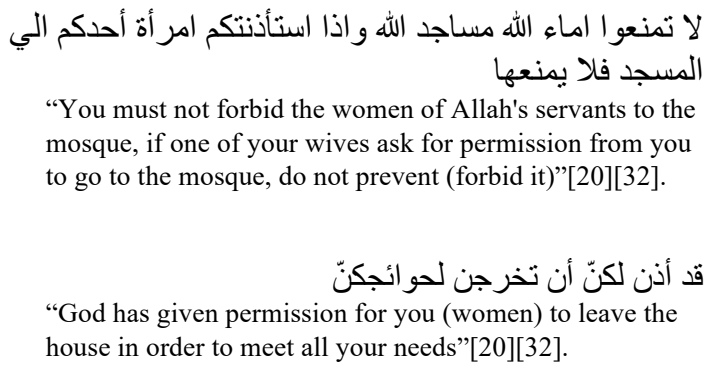

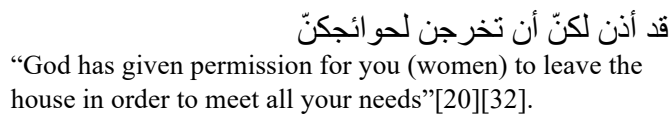

After Muhammadiyah compared with other traditions, it turns out that the hadith that prohibits women from going out of the house is in conflict with other traditions that are stronger in the transmission of history (al-riwayat) narrated by al-Bukhari and Muslim. In the al-Bukhari and Muslim narration, the Prophet (PBUH) actually forbids men who prevent women from leaving the house either for worship or other needs. In other words, (mafhum al-mukhalafah) that the Prophet (peace be upon him) ordered Muslims to give women the freedom to leave the house without any restrictions. The last two hadiths confirm that there is no obstacle for women to leave the house to do various activities, including marches, demonstrations or other interests. Muhammadiyah's rejection of misogynous traditions is not appreciative of gender equality, because many of these traditions are da'eef (weak). This is also confirmed by various other studies, that many misogynous traditions are of weak value.

\section{CONCLUSION}

The reading of gender discourse in Muhammadiyah is oriented to the glorification and appreciation of the involvement of women's active roles in public life. Muhammadiyah views that one of the objectives of Islamic law is to glorify and protect women. In Muhammadiyah's perspective, gender discourse is included into the category of al-mu'amalah aspect which is in the area of dynamization (al-mutaghayyirat) which continuously can change along with deference in time and place. This is different from the 


\section{REFERENCES}

of aqeedah (belief) and worship which is a area of altsawabit (static) which cannot be changed throughout the ages by means of addition or subtraction.

In reading the gender discourse, Muhammadiyah does not use the figures of the previous scholars who tend to be less appreciative of gender equality relations. Muhammadiyah placed ijtihad al-'ulama in accordance with its age; the classical ijtihad is for the past, not for the present cases. Muhammadiyah does al-ijtihad independently by holding on the Qur'anic texts and hadith to find and determine the provisions of gender relations that are more appreciative, just, and in accordance with the needs of modern women. Then, gender discourse in Muhammadiyah is developed according to the needs of modern women who are demanded to be active and participatory in social and political life.

The Koran and hadith according to Muhammadiyah are very appreciative of gender equality. Many Qur'anic values emphasize the active involvement of women in domestic or public life, as well as men. From many verses show that there is no domination of life for men or women, all of whom have the best contribution to give one of the deeds in the sight of Allah SWT. Although there are many traditions of the Prophet that are less appreciative of gender equality, historically are Da'eef (weak). Then, Muhammadiyah in the reception of proposition is very careful, and does not accept the hadith da'eef as legal evidence. Muhammadiyah only takes the traditions that are qualified as al-sahih (strongest/best) and al-hasan (strong/good), or al-da'eef (weak) traditions that are narrated in various lines that support each other so that they occupy the degree of alhasan lighairihi. Even if there are valid traditions, while the al-matan (text) is less appreciative in gender equality, Muhammadiyah interprets these traditions by looking at the history and reality that occurred in the past, so that legal reasons can be found that accompany the statement of the tradition. Thus the hadith can be understood according to the context.

\section{ACKNOWLEDGMENT}

In finishing and publishing this article, I thank very much to the chairman of the committee of the Borobudur International Symposium (BIS2019), Dr. Muji Setiyo who gave me the opportunity to present my work in this forum, so that I got a lot of valuable comments for the improvement of my article, especially from colleagues who were in the 22 nd roundtable discussion. I also thank to the Rector of Universitas Muhammadiyah Magelang, Mr. Ir. Muh Eko Widodo, MT who has provided funding and facilities for my seminar and publishing this work.
[1] K. Bhasin, Menggugat Patriarki: Pengantar tentang Persoalan Dominasi terhadap kaum Perempuan, 1st ed. Yogyakarta: Yayasan Bentang Budaya, 1996.

[2] Y. Ilyas, "Tajdid Muhammadiyah dalam Persoalan Perempuan," in Pandangan Muhammadiyah Terhadap Perempuan", Seminar Nasional Jelang Muktamar Muhammadiyah ke-47, Audotorium Kantor Pimpinan Pusat Muhammadiyah, Jln Cik Ditiro 23 Yogyakarta, 4 April 2015, 2015, no. April 2015, pp. 1-15.

[3] Tafsir, "Pandangan Muhammadiyah Tentang Perempuan," in "Pandangan Muhammadiyah Terhadap Perempuan", Seminar Nasional Jelang Muktamar Muhammadiyah ke-47, Audotorium Kantor Pimpinan Pusat Muhammadiyah, Jln Cik Ditiro 23 Yogyakarta, 4 April 2015, 2015, pp. 1-10.

[4] H. Moghisi, Feminisme dan Fundamentalisme Islam. Yogyakarta: LKiS, 2005.

[5] V. Kostenko, "Attitute towards Gender Equality and Perception of Democracy in The Arab World," WP BRP 50/SOC/2014, 2014.

[6] S. Glass, "Re-Understanding Religion And Support For Gender Equality In Arab Countries," Gend. Soc., vol. 32, no. 5, pp. 686-712, 2018.

[7] V. Kostenko, E. Ponarin, M. Shteiwi, and O. Strebkova, "Historical Legacies And Gender Attitudes In The Middle East,” Giza, Egypt, 1105, 2017.

[8] K. Klingorová and T. Havlíček, "Religion and gender inequality: The status of women in the societies of world religions," Morav. Geogr. REPORTS, vol. 23, no. 2, pp. 2-11, 2015.

[9] M. Gouda, "Gender Equality in Muslim-Majority Countries," Munich, Germany, No. 5883, 2016.

[10] Kusmana, "Menimbang Kodrat Perempuan antara nilai Budaya dan Kategori Analisis," Refleksi, vol. 13, no. 6, pp. 779-80, 2014.

[11] I. Muzammil, "Global Salafisme antara Gerakan dan Kekerasan," Teosof. J. Tasawuf dan Pemikir. Islam, vol. 3, no. 1, pp. 211-123, 2013.

[12] A. F. N. Fuad, "Da'wa and politics: Live Experience of the Female Islamist in Indonesia," in Contemporary Islam Dynamics of Muslim Life, Netherlands: Springer Nature B.V., 2019.

[13] M. A. Abdullah, "Pengaturan Hak-Hak Perempuan Dalam Undang-Undang Kesetaraan Dan Keadilan Gender (RUU KKG) Di Indonesia: Refleksi Kritis 
primadona bagi ajaran turun temurun pondok," Millati, vol. 3, no. 1, pp. 51-72, 2018.

[23] S. Anwar, "Fatwa, Purification and Dynamization: A Study of Tarjih in Muhammadiyah," Islam. Law Soc., vol. 12, no. 1, pp. 27-45, 2005.

[24] M. A. Abdullah, Fresh Ijtihad: Manhaj Pemikiran Keislaman Muhammadiyah di Era Disrupsi, 1st ed. Yogyakarta: Suara Muhammadiyah, 2019.

[25] M. C. Brooks and A. Mutohar, "Islamic School Leadership: A Conceptual Framework," OURNAL Educ. Adm. Hist., pp. 1-15, 2018.

[26] I. Ahmed, “A Review of Islamic Leadership,” J. Commer., vol. 6, no. 3, pp. 23-29, 2014.

[27] M. R. Muzakkir, "Pandangan Muhammadiyah tentang Kepemimpinan Perempuan,” Aisyah, 2017. [Online]. Available: http://www.aisyiyah.or.id/id/syiar/pengajian/pandangan -muhammadiyah-tentang-kepemimpinanperempuan.html. [Accessed: 28-May-2019].

[28] A. bi A. bin H. A. al-F. Al-'Asqalani, Fath al-Bari Syarh Sahih al-Bukhari. Beirut, Lebanon: dar alMa'rifah, 1959.

[29] A. bin A. bin S. bin H. Al-Dhahiri, Maratibul Ijma' fi al-Ibadat wa al-Mu'amalat wa al-'Itiqadat, Cet. 1. Beirut, Lebanon: Dar Ibn Hazm Li al-thaba'ah wa alNasr wa al-Tauzi', 1998.

[30] S. Anwar, "Manhaj tarjih dan Metode Penetapan Hukum dalam tarjih Muhammadiyah,” LPSI UAD, 2012. [Online]. Available: http://lpsi.uad.ac.id/manhajtarjih-dan-metode-penetapan-hukum-dalam-tarjihmuhammadiyah/. [Accessed: 10-Oct-2010].

[31] M. T. P. P. Muhammadiyah, Himpunan Putusan Tarjih Muhammadiyah. Yogyakarta: Suara Muhammadiyah, 2015.

[32] A. A. M. bin I. Al-Bukhari, Sahih al-Bukhari, Cet. 1. Beirut, Lebanon: Dar Ibn Katsir, 2001.
[22] A. Khozin, "Pemahaman Hadis Misoginis dalam Kitab Uqudul Lujayn di Pondok Pesantren An-Nur Semarang Latar Belakang Kitab kuning masih menjadi
[21] al-S. M. N. bin 'Umar Al-Jawi, Syarh 'Uqud alLijain fi bayan Huquq al-Zaujain. Kairo, Mesir: Dar alKutub al-Islamiyah.

[20] M. T. P. P. Muhammadiyah, Adabul Mar'ah Fil islam. Yogyakarta: Majelis Tarjih PP.Muhammadiyah, 1982.

Thought and Movement, Study on Personality and Idea of The Founding Figure (KH Ahmad Dahlan)," IJSTR, vol. 06, no. 08, pp. 155-159, 2017. 